этот список можно бесконечно продолжать. Многие из советских историков были вынуждены уснащать введения и предисловия своих книг цитатами из Ленина, Маркса или Сталина; ряд трудов был проникнут идеологией, но если абстрагироваться от этого, то мы поймем, что советская эпоха была богата талантливыми авторами высокой академической культуры. «Quaestio Rossica», таким образом, видит еще одной из своих задач реабилитацию научных результатов нескольких поколений несправедливо забытых или недооцененных сегодня исследователей. Журнал намерен переиздавать их статьи или фрагменты из их трудов, а также готовить ряд исследований биобиблиографического характера.

Итак, главная цель журнала - свидельствовать о своеобразии российской научной традиции, изучать различные этапы ее эволюции в плотном контексте и сопоставлении с многообразными европейскими, американскими и азиатскими научными школами русистики.

Первый номер журнала, статьи которого в основном посвящены Новому времени, объединяет работы, касающиеся различных аспектов русской истории, литературы и культуры в широком понимании этого слова. Особый раздел, открывающий номер, содержит статьи зарубежных исследователей, объясняющих свой интерес к России и раскрывающих их взгляд на ее современное состояние. Публикация такого рода материалов будет продолжена (на языке оригинала и в переводе на русский язык) и в последующих номерах.

Франсин-Доминик Личтенан

\title{
ОТ РЕДКОЛЛЕГИИ
}

Вниманию научного сообщества предлагается новый проект - международный научный журнал «Quaestio Rossica». Журнал основан в 2013 г. редакторским коллективом Института гуманитарных наук и искусств Уральского федерального университета. Идея создания журнала вызвала интерес ряда ведущих ученых России и зарубежья, мы им безмерно благодарны за поддержку и веру в осуществление проекта. Многие из них вошли в редакционный коллектив журнала. Обязанности главного редактора согласилась возложить на себя видный французский специалист по истории России профессор Франсин-Доминик Лиштенан.

В журнале на равных основаниях предоставляется место для публикации статей коллегам из зарубежных центров русистики. Объединение различных научных традиций всегда плодотворно и способствует выработке иммунитета к фальсификации и необоснованным выводам. Редколлегия надеется, что в публикуемых материалах обращение к новых источникам в освещении прошлого и настоящего будет сочетаться с конструктивным переосмыслением прежних схем, формированием новых концепций и многообразием подходов. 
Редколлегия отдает приоритет статьям, в которых привлекаются новые исторические источники и малоизвестные литературные и языковые явления, открывается процесс культурного взаимодействия синхронного и диахронного планов, анализируются новые артефакты.

Мы надеемся, что журнал войдет в международные индексы рецензируемых журналов, а российская тематика займет достойное место в мировой гуманитаристике.

Журнал открывают эссе ведущих зарубежных исследователей Хартмута Рюсса и Честера Даннинга о их интересе к российской истории.

Объединяющей проблемой первого номера (рубрика «Problema voluminis») стало время, когда определялись направления исторического пути России, - XVII-XVIII столетия, так как эта эпоха схожа с процессами, происходящими в современной России. Важной для российских историков является статья Шт. Трёбста, которую мы перевели с разрешения автора на русский язык. Статья освещает переломный для России год 1667-й и публикуется с предисловием профессора Рудольфа Пихои. Столь же новаторской является работа Ольги Кошелевой, освещающей процесс формирования интеллектуальной элиты России и приближение новой литературной эпохи. Новые материалы вводят статьи Дениса Ляпина, где использованы крестоприводные записи 1645 г., и Евгения Акельева об идеологическом контексте внешнего облика человека петровского времени.

B рубрике «Disputatio» публикуются статьи, касающиеся европейской идентичности России в связи с республиканскими интенциями. Эта тема представлена при освещении истории властных структур Псковской республики XV в. в статье Владимира Аракчеева и раскрытии республиканского дискурса XVIII столетия в статье Константина Бугрова. Новые источники вводятся в статье Сергея Черникова о российском генеральском корпусе 1725-1730 гг. Этот исследовательский вектор, связанный с обращение к новым историческим источникам, отвечает целям журнала. Столь же важной и постоянной может стать в журнале тема о деятельности иностранцев в России и россиян за рубежом. Урало-Сибирский регион интересен для иностранцев различными областями. Среди них было немало деятельных, образованных и масштабно мыслящих людей, для которых Россия становилась второй родиной. Деятельность и многогранность личности академика XVIII в. Якоба Штелина рассмотрена в статье Ф.-Д. Лиштенан. Рассказ об уральском инженере немце Андрее Кнауфе на основании новых данных начинает в этом номере Андрей Келлер.

В рубрике журнала «Dialogus» публикуется беседа автора глубокой и новаторской работы о литературном творчестве российских старообрядцев О. Журавель и профессора УрФУ Л. Соболевой.

C первого номера в разделе «Critika» мы начинаем публикации рецензий на вышедшие монографии. Перекликаются между собой аналитическая рецензия профессора УрФу Татьяны Снигиревой об академическом труде - «Истории литературы Урала XIV - XVIII вв.», 
где впервые открываются духовные поиски населения в многонациональном регионе со сложной исторической судьбой, и рецензия Шт. Требста на книгу финского исследователя Ярмо Котилайне (Jarmo Kotilaine) о российской политической и экономической экспансии в XVII столетии. Обе рецензии связаны с работами, где на основании конкретных фактов выстраиваются глубокие теоретические концепции, структурирующие историческое время и пространство России.

$* * *$

The Editorial Board would like to introduce a new international academic journal Quaestio Rossica founded in 2013 by the staff of the Institute of Humanities and Arts of Ural Federal University. This idea was greeted with great interest and approval of leading scholars in Russia and abroad alike, and we are infinitely grateful for the support and belief they give us and our project. Many of the scholars I mentioned have joined the Editorial Staff of the Journal. Professor Francine-Dominique Liechtenhan, a distinguished French historian of Russia has kindly agreed to become Editor-in-Chief.

The Journal gives foreign scholars of Russia possibilities for publication equal to those of their Russian peers, as the combination of a variety of academic traditions is always fruitful and helps acquire immunity to falsification and unfounded conclusions. Priority is given to articles written with reference to new historical sources and little-known literary and linguistic phenomena, reflecting cultural interaction (synchronic and diachronic alike), and analyzing new artifacts.

The Editorial Board expects the articles to be published in the Journal to refer to new sources in their account of the present and past, as well as contribute to constructive reconsideration of former patterns, and to the formation of new concepts, and demonstrate a multitude of approaches. Articles are published in accordance with the rules applied to academic journals included into citation indexes. We have a well-grounded hope that our effort will not be wasted, and the Journal will be included into international citation indexes of peer-reviewed journals, and Russian themes will occupy a fitting place in the world humanities. 